Jurnal Psikologi, Volume 1 Nomor 1, November 2020

\title{
JEBAKAN HIDUP DI DALAM LINGKARAN KEHIDUPAN MANUSIA SEJAK LAHIR HINGGA DEWASA
}

\author{
LIFE TRAP IN THE CIRCLE OF HUMAN LIFE FROM BIRTH TO ADULT Helma Kinaya \\ Putri Koo
}

Program Studi Psikologi, Fakultas Kedokteran, Universitas Lambung Mangkurat Jl.A.Yani km 36 Banjarbaru Kalimantan Selatan Kode Pos 70714, Indonesia Email : 2010914220005@mhs.ulm.ac.id No.Handphone :081346781936

\begin{abstract}
ABSTRAK
Tidak banyak dari kita yang menyadari bahwa sebenarnya setiap individu memiliki jebakan yang menempel dalam diri mereka. Kebanyakan dari itu belum sepenuhnya menghilang atau bahkan belum bisa diobati. Terkadang banyak dari kita tidak menyadari adanya jebakan hidup yang mengekang hidup kita. Jeffrey Young, Ph.D and Janet Klosko, Ph.D, (2013) menjelaskan konsep life trap atau jebakan kehidupan. Di dalam buku tersebut jebakan kehidupan digambarkan sebagai pola hidup negatif yang terjadi berulang-ulang sehingga menghambat kita mencapai apa yang kita inginkan. Life Traps yang paling sering dialami oleh setiap individu dikelompokkan menjadi 11 macam, yaitu : Abandonment, Mistrust Abuse, Emotional Deprivation, Social Exclusion, Dependece, Vulnerability, Defectiveness, Failure, Subjugation, Unrelenting Standart, Entitlement. Tujuan penelitian ini untuk mengetahui jebakan hidup di dalam lingkaran kehidupan manusia sejak lahir hingga dewasa agar setiap individu lebih mengerti dimana posisinya dan apa jebakan yang masih mengekangnya dengan harapan ke depannya setiap individu bisa lebih mengerti bagaimana cara menghadapi jebakan hidup tersebut dan menemukan jalan keluar terbaik demi mencapai kesejahteraan hidup. Metode yang digunakan adalah kajian literatur. Hasil penelitian menunjukkan bahwa lingkungan, mindset, pola asuh, dan karakteristik kepribadian mempengaruhi munculnya jebakan hidup dari setiap individu.
\end{abstract}

Kata kunci : Jebakan hidup, kehidupan, individu

\section{ABSTRACT}

Not many of us realize that actually every individual has a trap stuck within them. Most of them have not completely disappeared or have not even been treated. Sometimes many of us don't realize that there are life traps that grip our lives. Jeffrey Young, Ph.D and Janet Klosko, Ph.D, (2013) explain the concept of life traps. In the book, life traps are described as negative life patterns that occur repeatedly, preventing us from achieving what we want. Life Traps that are most often experienced by each individual are grouped into 11 types, namely: Abandonment, Mistrust Abuse, Emotional Deprivation, Social Exclusion, Dependence, Vulnerability, Defectiveness, Failure, Subjugation, Unrelenting Standards, Entitlement. The purpose of this research is to find out the traps of living in the circle of human life from birth to adulthood so that each individual understands better where his position is and what the traps are still holding him back with the hope that in the future each individual can better understand how to deal with these life traps and find the best solution for the sake of achieve 
a prosperous life. The method used is literature review. Research result shows that the environment, mindset, upbringing, and personality characteristics influence the emergence of the life trap of each individual.

Keywords: Life trap, life, individua

\section{Pendahuluan}

Tidak banyak dari kita yang menyadari bahwa sebenarnya setiap individu memiliki jebakan yang menempel dalam diri mereka. Kebanyakan dari itu belum sepenuhnya menghilang atau bahkan belum bisa diobati. Kebanyakan pula jebakan tidak dapat ditemukan dengan mudah jika pribadi masing-masing tidak mencari tahunya lebih dalam melalui alam sadar serta alam bawah sadar mereka. Jebakan yang dimaksud disini tidak lain adalah trauma dan kebiasaan buruk dari masa lalu. Jebakan atau disebut juga sebagai Life Traps adalah suatu kondisi yang tanpa kita sadari kita miliki, biasanya berbentuk belief system menyangkut pandangan diri seseorang dan lingkungannya dengan cara yang salah. Faktor yang memengaruhi Life Traps bisa berasal dari perlakuan yang diberikan keluarga, teman, dan orang-orang sekitar lainnya melalui pola asuh tumbuh kembang yang kurang tepat di masa kecil setiap individu. Life Traps merupakan penjara dari pengalaman buruk kita di masa lalu. Kejadian-kejadian itu menetap sampai kita dewasa dan seringkali menimbulkan situasi dimana kita merasa direndahkan, diejek, dilecehkan, dianiaya, ditinggalkan, dan sebagainya dalam kurun waktu berbeda-beda tergantung kondisi. Menurut Jeffrey E. Young, Ph.D. dan Janet S. Klosko, yang merupakan Cognitive Therapist dari Amerika mengatakan berdasarkan pengalaman praktik terapi, mereka mengidentifikasikan dan mengelompokkan 11 macam Life Traps yang paling sering dialami oleh setiap individu, yaitu : Abandonment, Mistrust Abuse, Emotional Deprivation, Social Exclusion, Dependece, Vulnerability, Defectiveness, Failure, Subjugation, Unrelenting Standart, Entitlement.

\section{Tinjauan Literatur}

\section{Abandonment}

Kondisi dimana seseorang merasa ditinggalkan atau dibuang oleh orang-orang terdekatnya, diikuti perasaan berempati terhadap diri sendiri, kesepian, dan kesedihan. Disebabkan kurangnya kasih sayang serta rasa aman dari orang sekitar. Seseorang dengan jebakan ini akan cenderung mengulangi kejadian yang pernah dialaminya di masa lalu tanpa disadari dikarenakan dirinya merasa layak untuk diperhatikan. Perilaku yang muncul ketika beranjak dewasa biasanya berupa empati lebih terhadap orang lain, sering merasa putus asa, senang merendahkan diri, dan selalu mencoba mencari teman serta memposisikan diri sebagai orang terbuang dan tidak penting dalam suatu kelompok. Mulyana, Ibnu Taufan; Sumadi; Chaerunnisa, Madiha Dzakiyah (2018) mengatakan di penelitian mereka bahwa dalam menjalani kehidupan berumah tangga, selalu ada permasalahan yang muncul dan dapat memicu keinginan dan keberanian seorang suami untuk memilih meninggalkan istri dan anak atau yang disebut dengan menelantarkan rumah tangga. Dampak psikologis istri akibat ditinggalkan suaminya di Desa Ciherang, Kabupaten Banjarsari adalah sebagai berikut: (a). Istri merasakan sakit hati, dendam dan kebencian yang dalam akibat diabaikan oleh suaminya selama lebih dari 2 tahun. (b). Kebiasaan menangis karena kejadian itu seakan tak terduga. Dengan kata lain, dia masih tidak percaya suaminya meninggalkannya tanpa memberi kabar. Dan ini berdampak pada berkurangnya nafsu makan. 


\section{Mistrust Abuse}

Kondisi dimana seseorang merasa tidak aman dan curiga secara berlebihan karena takut orang lain akan bersikap buruk kepadanya demi keuntungan. Disebabkan kurangnya rasa aman dalam lingkungan keluarga, terlalu sering dibohongi dan diberi harapan palsu semasa kecilnya. Seseorang dengan jebakan ini cenderung menganggap bahwa orang lain tidak dapat dipercaya, hanya ingin menipu, menyakiti, dan mengambil kesempatan dalam kesempitan sebagai upaya mengambil keuntungan dari dirinya. Perilaku yang muncul ketika beranjak dewasa biasanya berupa asumsi dan persepsi buruk terhadap orang lain, pesimis, serta selalu berpikiran negatif terhadap lingkungan sekitarnya. Irdhanie, A., \& Cahyanti Ika, Y. (2013) menyatakan adult romantic attachment yang dimaksud adalah pola kelekatan yang dimiliki dewasa pada pasangannya. Adult romantic attachment ditentukan oleh empat komponen yakni ikatan emosi, kebergantungan, kepercayaan dan penerimaan diri. Keempat komponen ini dapat mengkategorikan dewasa menjadi empat jenis pola kelekatan diantaranya secure, preoccupied, dismissing dan fearful attachment.

\section{Emotional Deprivation}

Kondisi dimana seseorang merasa tidak diperhatikan dan tidak dipedulikan oleh orangorang. Disebabkan ketika dimasa kecilnya seseorang tidak mendapatkan kehangatan, kasib sayang, dan cinta dari keluarga. Seseorang dengan jebakan ini cenderung menyakini bahwa dirinya tidaklah penting dan tidak ingin mempedulikan orang lain sebagai balasannya serta turut mencari perhatian untuk dirinya sendiri. Perilaku yang muncul ketika beranjak dewasa biasanya berupa bergonta-ganti pasangan, teman dekat, pekerjaan, dan lainnya untuk mendapatkan kesenangan serta perhatian yang belum pernah didapat sebelumnya. Kebiasaan tidak dipedulikan dan tidak mempedulikan orang lain serta upaya bertualang mencari perhatian membuat mereka berusaha menjadikan orang lain sebagai tumbal dsn seringkali berganti-ganti pasangan sebagai bentuk upaya pelampiasan.

\section{Social Exclusion}

Kondisi dimana seseorang merasa asing dalam pergaulan sosialnya. Disebabkan oleh ejekan dan penilaian negatif dari lingkungannya. Seseorang dengan jebakan ini cenderung merasa tidak diterima dalam kelompok yang mekuat dirinya sebab merasa ada sesuatu yang kurang dari dirinya dan justru dimiliki oleh orang lain. Perilaku yang muncul ketika beranjak dewasa biasanya berupa pengasingan diri dan enggan membangun relasi dengan orang luar. Perasaan tidak diterima di dalam benak mereka memiliki dampak sangat spesifik terhadap keseharan mental. Merasa bahwa dunia tidak adil untuk diri mereka sendiri dan akhirnya menjadi pribadi yang tertutup, hal inilah yang akhirnya membedakan mereka dengan individu lainnya dalam membangun hubungan dengan sesama.

\section{Dependece}

Kondisi dimana seseorang merasa harus bergantung kepada orang lain dan tidak bisa mengambil keputusan untuk dirinya sendiri. Disebabkan ketika masih kecil seorang individu dituntut untuk menuruti apa yang dikatakan oleh figur mayoritas, seperti orang tua maupun kerabat. Seseorang dengan jebakan ini cenderung kesulitan mengambil keputusan dan selalu meminta pertimbangan dari orang lain sebagai jawaban atas pertanyaan-pertanyaan dalam benaknya. Perilaku yang muncul ketika beranjak dewasa biasanya berupa perasaan takut salah, kesulitan membangun hidup, dan hanya bisa bergantung kepada orang lain saja. Ketergantungan yang mereka tanam berkembang menjadi suatu penyakit yang menjadikan mereka seperti parasit dalam kehidupan orang lain. 


\section{Vulnerability}

Kondisi dimana seseorang merasa hidup dalam kondisi yang salah dan buruk, dimana merasa bahwa dirinya hidup dalam dunia yang penuh dengan kekejaman dan kepedihan. Disebabkan oleh lingkungan sekitar yang dahulunya sering memberikan efek jera dan takut dengan cara menakut-nakuti atau menceritakan kejadian buruk yang terjadi di luar rumah. Seseorang dengan jebakan ini cenderung ragu dan takut untuk keluar dari zona nyamannya. Perilaku yang muncul ketika beranjak dewasa biasanya berupa ketakutan berlebih, keyakinan buruk, dan kurangnya rasa percaya kepada orang lain.

\section{Defectiveness}

Kondisi dimana seseorang merasa tidak sempurna dan senang menyalahkan diri sendiri karena ragu apakah dirinya dihargai oleh orang lain atau tidak. Disebabkan kritikan bertubi-tubi dan perasaan tidak dihargai serta diharapkan ketika masih dalam zona berkembang di masa kecil. Seseorang dengan jebakan ini cenderung merasa harga dirinya begitu rendah dan selalu merasa lebih buruk dibandingkan orang lain. Perilaku yang muncul ketika beranjak dewasa biasanya berupa kurang percaya diri, tidak mau terbuka dengan orang lain, dan perasaan takut salah.

\section{Failure}

Kondisi dimana seseorang merasa takut akan kegagalan secara berlebihan, merasa dirinya selalu salah, dan pecundang terpayah. Disebabkan oleh trauma dramatisir dari kegagalan di masa lalu akibat tidak memenuhi apa yang dituntut oleh keluarga ataupun figur otoritas lainnya. Seseorang dengan jebakan ini cenderung berpikiran bahwa dirinya selalu gagal dan tidak dapat memenuhi persyaratan dimata orang lain. Perilaku yang muncul ketika beranjak dewasa biasanya berupa buruk, lemah, dan ragu-ragu atas apa yang harus dia putuskan.

\section{Subjugation}

Kondisi dimana seseorang merasa dirinya harus menuruti apa yang dikehendaki oleh orang lain sesuai dengan perintah sebagaimana mestinya dan selalu berusaha menyenangkan hati orang lain tanpa memedulikan kesenangan dirinya sendiri. Disebabkan oleh pola asuh orang tua yang terlalu keras dimana anak harus selalu menuruti apa yang mereka katakan. Seseorang dengan jebakan ini cenderung berpikiran bahwa orang lain selalu lebih tahu dibandingkan dirinya dan mereka selalu benar atas apa yang mereka katakan. Perilaku yang muncul ketika beranjak dewasa biasanya berupa kurang baik dalam membina kehidupan sosial dan pekerjaan, terutama dengan sosok pemimpin yang otoriter. 


\section{Unrelenting Standart}

Kondisi dimana seseorang merasa harus menjadi yang terbaik dengan standar yang telah ditentukan, biasanya dalam bentuk pencapaian yang sangat tinggi dan selalu mementingkan prestasi. Biasanya individu dengan jebakan hidup ini selalu dituntut untuk mencapai suatu pencapaian dengan standar yang tinggi. Disebabkan oleh beban timpaan yang diberikan oleh orang tua maupun keluarga ketika masih kecil dengan cara memaksakan kemampuan dan impian anak yang mana bertujuan agar anak dapat menjadi apa yang mereka harapkan. Seseorang dengan jebakan ini cenderung berlebihan dalam karirnya dan kurang memperhatikan perasaan orang lain. Perilaku yang muncul ketika beranjak dewasa biasanya berupa keinginan untuk menjadi nomor satu dalam segala aspek meskipun mereka sendiri merasa belum pernah mencapai apa-apa.

\section{Entitlement}

Kondisi dimana seseorang merasa selalu berhak atas apa yang diinginkannya. Disebabkan pola asuh orang tua yang senang memanjakan mereka sewaktu masih kecil dengan mengabulkan segala permohonan dan keinginan anak atau dengan kata lain dengan cara memanjakan seorang anak secara berlebihan dan mengabulkan segala sesuatu yang diinginkan oleh seorang anak dalam kondisi apapun, baik saat sedang senang maupun sulit. Hal ini menyebabkan anak menjadi sosok yang egois dan ingin menang sendiri serta tidak pandai dalam mengatur pendirian dan tidak bisa memperhatikan perasaan orang lain. Seseorang dengan jebakan ini cenderung tidak dapat mengontrol diri dan lemah dalam pendisiplinan diri. Perilaku yang muncul ketika beranjak dewasa biasanya berupa keegoisan serta emosi yang seringkali meledak-ledak.

\section{Metode Penelitian}

Penelitian ini sendiri tidak menggunakan subjek penelitian karena teknik analisis data yang digunakan merupakan kajian literatur. Alat ukur dengan menggunakan beberapa hasil penelitian terdahulu yang berhubungan dengan jebakan hidup, individu, dan faktor-faktor penyebabnya. Prosedur penelitian dilakukan dengan cara membahas hasil-hasil penelitian terdahulu yang telah teruji hasilnya dalam variabel-variabel didalam penelitian, yaitu jebakan hidup, individu, dan faktor-faktor penyebabnya. Data yang diperoleh akan dianalisis dengan menggunakan teknik pembahasan literatur karena mengambil teknik analisis kajian literatur. Penelitian ini merupakan desain untuk tesis, sehingga untuk saat ini proses hasil penelitian diambil dari literatur penelitian terdahulu dengan mengandalkan sumber bacaan dari berbagai macam peneliti yang memahami permasalahan jebakan hidup ini.

\section{Proses Pengumpulan Data}




\begin{tabular}{|c|c|}
\hline Peneliti & Daud Antonius \\
\hline Definisi & $\begin{array}{l}\text { Life Trap adalah jebakan yang tanpa sadar dimiliki oleh setiap dari individu, } \\
\text { biasanya dibentuk oleh nilai atau belief system yang salah yang menyangkut } \\
\text { cara pandang terhadap diri sendiri dan lingkungan. Life traps juga dapat } \\
\text { dibentuk dari pengaruh serta perlakuan oleh orang terdekat, dan yang lebih } \\
\text { berbahaya bisa diciptakan oleh orang tua melalui pola asuh yang kurang tepat } \\
\text { di masa kita kecil. Life Traps adalah perangkap yang tercipta dari pengalaman } \\
\text { buruk di masa lalu atau masa kecil kita. Seperti kejadian: Pernah ditinggalkan, } \\
\text { dikritik berlebihan, terlalu sering dibandingkan, pemah dilecehkan, diambil } \\
\text { keuntungan dari orang lain, pernah dibully atau diasingkan oleh lingkungan } \\
\text { sosial, kasih sayang dan penerimaan yang tidak cukup, sering ditakut-takuti, } \\
\text { dibentak berlebihan, terus diperintah, pola asuh orang tua yang over protektif, } \\
\text { orang tua yang selalu memanjakan anak, dan lainnya. Intinya kejadian tidak } \\
\text { menyenangkan tersebut muncul pada saat kita masih dalam proses } \\
\text { pembentukan belief system. }\end{array}$ \\
\hline Cakupan & Jebakan hidup, individu, mindset \\
\hline Peneliti & Jeffrey Young, Ph.D and Janet Klosko, Ph.D \\
\hline Definisi & $\begin{array}{l}\text { Konsep life trap atau jebakan kehidupan. Di dalam buku tersebut jebakan } \\
\text { kehidupan digambarkan sebagai pola hidup negatif yang terjadi berulang-ulang } \\
\text { sehingga menghambat kita mencapai apa yang kita inginkan. Jebakan kehidupan } \\
\text { ini dapat berawal jauh di masa lalu, saat yang mungkin kita sudah lama } \\
\text { melupakannya, dan berulang terus-menerus dengan pola yang tidak disadari } \\
\text { sehingga yang kita menjadi terbiasa dengannya. Apalagi pola ini biasanya ini } \\
\text { merupakan bagian dari strategi diri kita untuk mempertahankan hidup. }\end{array}$ \\
\hline Cakupan & Jebakan hidup, individu, pola hidup \\
\hline Peneliti & Daud Antonius \\
\hline Definisi & $\begin{array}{l}\text { Melepaskan diri dari berbagai jebakan hidup Setelah mengetahui beberapa } \\
\text { jebakan hidup yang mungkin kita iki, kita juga secara langsung bisa menyadari } \\
\text { kebutuhan apa saia yang sebenarnya belum cukup terpenuhi. Keamanan, } \\
\text { hubungan, kemandirian, harga diri, ekspresi diri dan kebutuhan akan batasan } \\
\text { adalah beberapa hal yang perlu kemudian kita lengkapi dalam rangka } \\
\text { melepaskan diri dari Life Traps. }\end{array}$ \\
\hline Cakupan & Jebakan hidup, individu, teknik \\
\hline Peneliti & Daud Antonius \\
\hline Definisi & $\begin{array}{l}\text { 1. Kebutuhan : need of basic safety (kebutuhan akan keamanan dasar } \\
\text { yang tidak terpenuhi) } \\
\text { - Abandonment (kurang rasa aman, kehilangan orang yang dicintai, }\end{array}$ \\
\hline
\end{tabular}




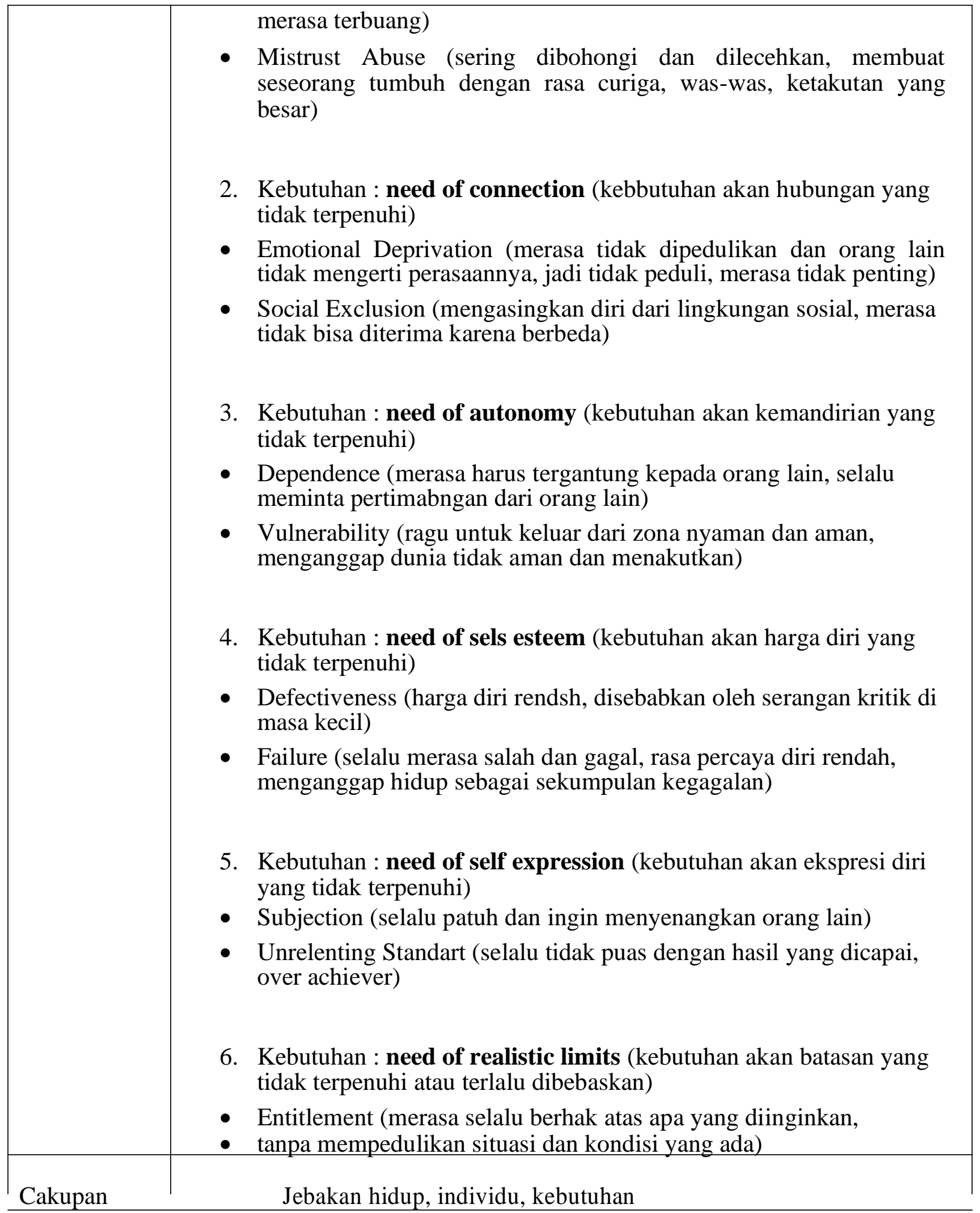

Ada pula pandangan menurut Daud Antonius dengan memperhatikan hubungan jebakan hidup dan DISC. Profil DISC tidak hanya memperhatikan konteks kepribadian dan perilaku, namun juga kecenderungan denga jebakan hidup, yaitu : 


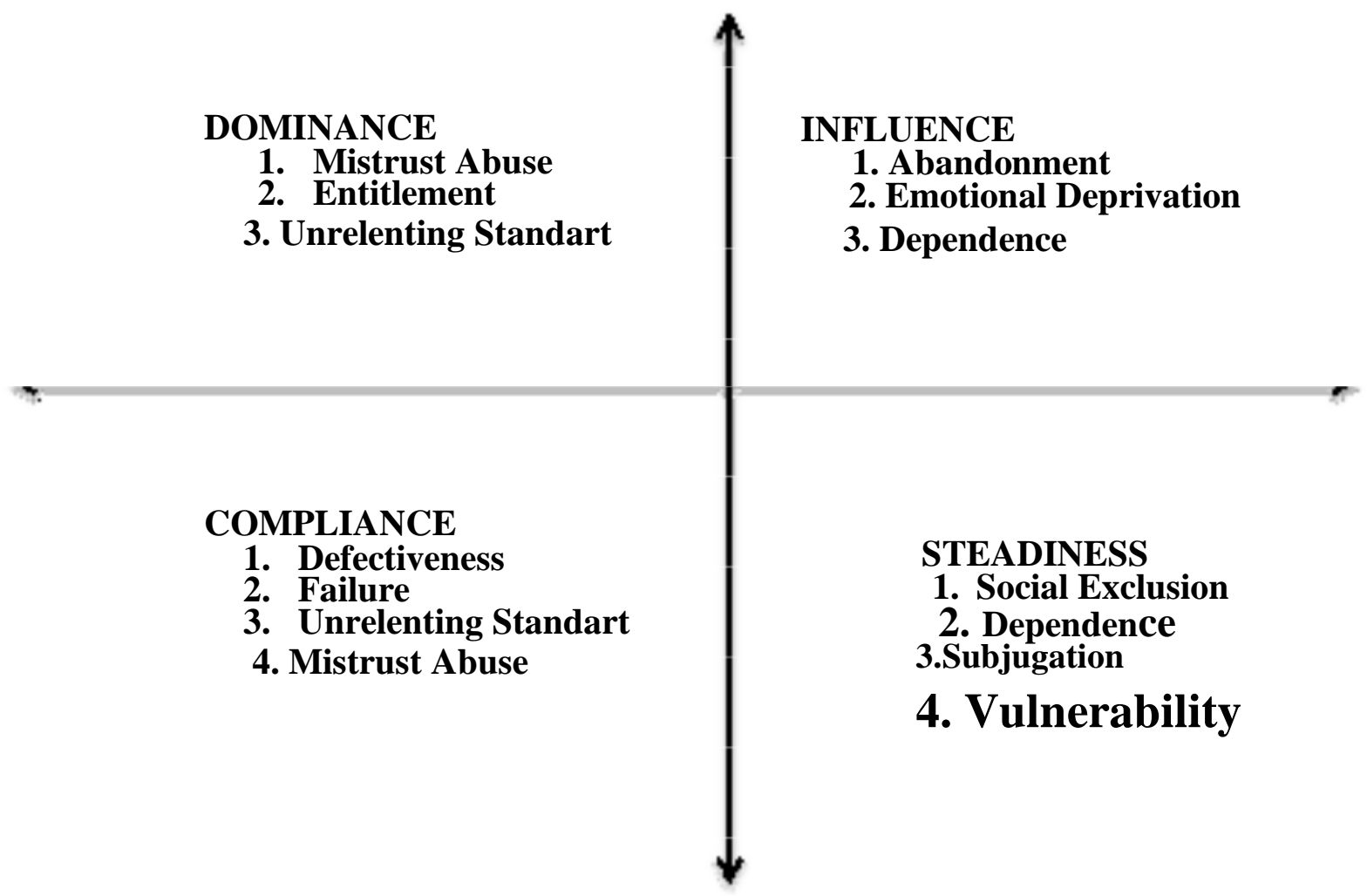

\section{Kesimpulan}

Jadi jebakan hidup atau life traps adalah suatu kondisi dimana pasti dimiliki oleh setiap individu di muka bumi yang mana kondisi tersebut berasal dari pengalaman yang pernah dialami di masa lalu dan memengaruhi kehidupan setiap individu hingga dewasa. Jebakan hidup tidak terlahir begitu saja dan harus segera diatasi. Karena kepribadian dan perilaku seseorang juga dapat dipengaruhi oleh jebakan hidup tersebut. 


\section{Daftar Pustaka}

Abbas, E. W., \& Erlyani, N. (2020). Menulis di Kala Badai Covid-19.

Abbas, E. W. (2020). Ersis Writing Theory: Cara Mudah Menulis.

Abbas, E. W. (2020). Menulis Artikel Jurnal Internasional.

Antonius. D, The Secret of Mindset, Bandung : Penerbit Psikologi ID, 2020

Antonius. D, Identity, Bekasi : Penerbit Psikologi ID, 2020

Jeffrey Young, Ph.D and Janet Klosko, Ph.D,. Reinventing Your Life, Breakthrough Program to end Negative Behaviour and Feel Great Again, 2013

MULYANA, Ibnu Taufan; SUMADI, Sumadi; CHAERUNNISA, Madiha Dzakiyah.

HUKUM DAN DAMPAK PSIKOLOGIS PENELANTARAN ISTERI OLEH SUAMI MENURUT ULAMA DESA CIHERANG KECAMATAN BANJARSARI KABUPATEN CIAMIS. Istinbath | Jurnal Penelitian Hukum Islam, [S.1.], v. 13, n. 2 , p. 57-84, oct. 2020. ISSN 1907-8064. Available at: <http://www.risetiaid.net/index.php/istinbath/article/view/461 > . Date accessed: 11 nov. 2020.

Irdhanie, A., \& Cahyanti Ika, Y. (2013). Adult Romantic Attachment pada Dewasa Muda yang Mengalami Childhood Abuse. Jurnal Psikologi Klinis dan Kesehatan Mental, 2(02), 20-36.

Sazali, H., \& Rozi, F. (2020). Belanja Online dan Jebakan Budaya Hidup Digital pada Masyarakat Milenial. JURNAL SIMBOLIKA: Research and Learning in Communication Study, 6(2), 85-95.

Alisyahbana, T. (2020). Manusia Dalam Pandangan Psikologi. Deepublish.

Yarmi, G. (2014). Meningkatkan Kemampuan Menulis Kreatif Siswa Melalui Pendekatan Whole Language Dengan Teknik Menulis Jurnal. Perspektif Ilmu Pendidikan, 28(1), 8-16.

Mardin, H., Baharuddin, B., \& Nane, L. (2020). Pelatihan Cara Menulis Sitasi Dan Daftar Pustaka Jurnal Format Apa StyleMenggunakan Aplikasi Mendeley. Jurnal Abdidas, 1(3), 137-143.

Wekke, I. S. (2019). Menulis Artikel Jurnal.

Aridarmaputri, G. S., Akbar, S. N., \& Yuniarrahmah, E. (2016). Pengaruh jejaring sosial terhadap kebutuhan afiliasi remaja di program Studi Psikologi Fakultas Kedokteran Universitas Lambung Mangkurat. Jurnal Ecopsy, 3(1).

MUIN, F. (2017). Phonemic interference of local language in spoken english by students of english Department of Lambung Mangkurat University. Journal of Language Teaching and Research, 8(1).

Karina, I., Hatta, G. M., \& Prihatiningtyas, E. (2019). Studi habitat mikro kayu kuku (Pericopsis mooniana) dalam upaya budidaya di KHDTK pendidikan dan pelatihan Universitas Lambung Mangkurat. Jurnal Sylva Scienteae, 1(1), 81-91.

Basuki, S. (2017). Partisipasi Mahasiswa Dalam Kegiatan Olahraga Dan Sarana Prasarana Pendukung Pada Universitas Lambung Mangkurat. Multilateral Jurnal Pendidikan Jasmani dan Olahraga, 16(1).

Maulidina, W. D., Istiqomah, E., \& Rachmah, D. N. (2020). HUBUNGAN MODAL PSIKOLOGIS DENGAN KECERDASAN EMOSIONAL PADA DOSEN UNIVERSITAS LAMBUNG MANGKURAT. Kognisia prodi Psikologi FK ULM, $1(2), 169-174$.

Amka, A. (2020). LAPORAN PENELITIAN: PARTISIPASI SOSIAL MAHASISWA TUNARUNGU DI UNIVERSITAS LAMBUNG MANGKURAT.

Aziz, M. (2017). Pemodelan Algoritma Genetika Pada Sistem Penjadwalan 
Perkuliahan Prodi Ilmu Komputer Universitas Lambungmangkurat. KLIKKUMPULAN JURNAL ILMU KOMPUTER, 1(1), 67-79.

Arman, J., Hidayatullah, M. S., \& Mayangsari, M. D. (2020). PERANAN

KECERDASAN ADVERSITAS TERHADAP KEMAMPUAN BERPIKIR KRITIS PADA MAHASISWA YANG AKTIF ORGANISASI DI FAKULTAS KEDOKTERAN UNIVERSITAS LAMBUNG MANGKURAT. Kognisia prodi Psikologi FK ULM, 2(1), 42-50.

Nawawi, M., \& Bachri, A. A. (2019). PENGARUH REMUNERASI DAN MOTIVASI KERJA TERHADAP KINERJA PEGAWAI NEGERI SIPIL (PNS) Studi Pada Kantor Rektorat Universitas Lambung Mangkurat Banjarmasin. JWM (Jurnal Wawasan Manajemen), 6(3), 285-294. 